\title{
INFORMATION DELICTOLOGY, AS A NEW LEGAL SCIENCE: ISSUES OF THE PRINCIPAL SENSE-MAKING ELEMENTS FORMATION
}

\section{Zaiarnyi O. A.}

\section{INTRODUCTION}

Scientific rationale of self-consistency of information delicts pertaining to unlawful acts committed by the participants of information relations, the existence of the wide range of causes and conditions conducive to the commitment of that category of delicts, as well as the need for approval and implementation of specific programs for the prevention of information statutory violations at the state level have led to the actualization of theoretical basis formulation of a complex legal science able to cover the above mentioned issues within its research.

Information delictology has become the legal science with subjectfunctional properties ensuring the performance of corresponding tasks in various areas of information activity.

\section{Definition of Information Delictology as a Science}

Currently, there is no uniform knowledge of the essence of information delictology as a science in legal literature.

Y. Maksymenko suggests the definition of that legal science as the following: "The body of knowledge of information delicts and tortness as a large-scale negative information and legal phenomenon containing the determinants of the delinquent's unlawful conduct and personality with the purpose of developing and applying of adequate measures aimed to counteract information violations" 1 .

In his definition of information delictology through the prism of "legal delictology in information law", V. Tsymbaliuk characterizes the first of those concepts as the complex academic discipline equal to the

1 Максименко Ю. Є. Інформаційна деліктологія: проблемні питання. URL: http://goal-int.org/informacijna-deliktologiya-problemni-pitannya/ 
specific branch institute, namely, the science of information violations and its methodology ${ }^{2}$.

Generalization of the given views on the essence of information delictology demonstrates, that despite the lack of a single academic notion of the concept it primarily covers a complex legal science with information delicts, their peculiarities, elements, causes and conditions facilitating information tortness as a subject of its research.

Based on that, we suggest a specific definition of information delictology as a complex legal science formed out of the knowledge of the system of information delicts as well as their features, peculiarities of elements, causes and conditions conductive to their commitment along with the preventive actions regarding to information statutory violations, legal and social values protection aimed at the academic formulation of techniques and programs of information tortness reduction and the provision of information legal order within the society and the state ${ }^{3}$.

\section{The Subject Matter and the Object of Study of Information Delictology as its Constructive Elements, Their Nature and Definition Problems}

It is common knowledge that any science evolves only under the circumstances of its subject of research separation out of the system of objective and subjective connections of the reality phenomena.

Understanding of a particular nature of information delictology lies in comparison between the subject matter of the science and its object of study.

Academic science considers the object of study as something unstudied and requiring scientific research as well as opposing the acquired knowledge of objects and phenomena of the material world ${ }^{4}$.

Philosophy defines the object of academic study as "objective features, connections and relationship involved in the cognitive process",

2 Цимбалюк В. С. Охорона та захист інформаційних ресурсів на засадах юридичної деліктології. Правова інформатика. 2007. № 4 (16). С. 23.

Арістова I. В., Баранов О. А., Дзьобань О. П. та ін. Юридична відповідальність за правопорушення в інформаційній сфері та основи інформаційної деліктології : монографія. Київ: КВІЦ, 2019. С. 144.

4 Петровская О. В. Магистратура: проблемы методики преподавания юридических дисциплин : монография. М.: Высшее образование, Юрайт-Издат, 2012. URL: http://base.garant.ru/58085321/. 
Defining the object of study O. Rudenko makes an important clarification: "What is meant here is not just objective reality or givenness, but the fact that any phenomenon becomes the object of knowledge provided that it is involved in the cognitive process ${ }^{6}$ ".

Taking into account the above mentioned clarifications, information delictology studies information tortness as the object of scientific cognition.

For the purposes of the given paper, the last concept can be defined as a system-structural socio-public phenomenon stipulated by illegal needs or interests, which is entitative regarding to illegal use of information, communication technologies, information privacy breach, invasion of information infrastructure or information legal order as a whole, manifested at a certain area during a particular period of time and entails the application of organizational and legal measures aimed to prevent information delicts along with the social values security and protection pertaining to information area.

The provided definition demonstrates that information tortness poses not just a body of information delicts, but an integral systematic phenomenon caused by the ongoing social processes and factors stimulating the violation of information and legal provisions.

According to such interpretation tortness represents the form of social behavior for the members of informational society that violates the legally valid functioning of various kinds of social values protected by the state.

On the other hand, the emergence and development of information tortness has been the indicator of a separate group of factors formation (causes and conditions) as well as the regularities encouraging the participants of information relations to illegal conduct that violates information legal order established by the law, information rights of a person or proper functioning of information infrastructure. All the above mentioned demonstrates negative antisocial character of information tortness and its connection with illegal interests and needs of the participants of information relations.

5 Руденко О. В. До проблеми співвідношення об'єкта та предмета наукового пізнання. Міжнародна наукова конференція “Дні науки філософського фр-ту-2005” : матеріали доповідей та виступів. Частина 2. К.: ВПЦ “Київський університет”, 2005. C. 80 .

${ }^{6}$ Ibidem. 
Hence, information tortness as the object of research combines the following elements:

1) a body of information delicts incorporated with cause-effect complex, the subjects and the field of commitment as well as the preventative measures that create anti-social and system-structural phenomenon, namely, information tortness posing direct threat for national information safety, public information legal order as well as rights and legitimate concerns of the participants of information relations;

2) the properties of information tortness characterizing socio-legal and system-structural features of the given large-scale illegal phenomenon reveal its state, regional, generic or specific peculiarities as the illegal social phenomenon;

3) countermeasures to information tortness, in particular, administrative and criminal remedies, state programs aimed to prevent information delicts, enforcement of information legal order as a whole;

4) information area as objective and territorial space of information tortness emergence and development and regularity of its existence encouraging the participants of information relations to legal prohibitions infringement along with illegal use of information and disobedience of the established order of information activity exercising.

Representing one of the fundamental categories of the science of information delictology "object" is revealed in its particular components, in other words, in the phenomena, factors and processes that were discovered previousely and can cause emergence or developing of information tortness.

According to general scientific meaning "a subject of a science" is a category that means a set of issues studied; any physical objects researched and deliberated ${ }^{7}$.

As it was noticed by M. Alekseev, a subject of a science has been the result of reality "processing", its known stylization. Hence, there are as many scientific styles as subjects. The same reality, for example, Beethoven sonata, is the sum of mechanical movements in the opinion of a legal scholar and a piece of music full of content and sense for a

${ }^{7}$ Петровская О. В. Магистратура: проблемы методики преподавания юридических дисциплин : монография. М.: Высшее образование, Юрайт-Издат, 2012. URL: http://base.garant.ru/58085321/. 
cultural studies scholar. Correspondingly, the structure of the subject depends on the objectives of reality and our demands regarding to it ${ }^{8}$.

There is no integrated view of the subject among the representatives of information delictology. The main cornerstone of scientific disputes on the above mentioned problematics has been the definition of the structural elements of information delictology subject of study.

According to Y. Maksymenko :"The subject matter of information delictology constitutes information violations committed by means of information telecommunication technologies and communication facilities as well as those occurring in connection with infringement of right for creation, gathering, receiving, storing, using, distributing, safety and protection of information"9.

In his turn, V. Tsymbaliuk considers information infringement to be the subject of information delictology ${ }^{10}$.

Taking into account the academic views mentioned above, the subject matter of information delictology can be defined as a body of information delicts, that were committed at a particular territory of the state during a specific period of time, that create information tortness along with their structure, status, growth rates, causes and conditions for their commitment and socio-legal personality characteristic of the information and legal prohibitions offender, state programs of information legal order and national information safety.

Proceeding from the contents of the definition provided, the basis of the subject matter of information delictology is the whole variety of information delicts and related social phenomena as well as processes limited by specific space-time boundaries, field of commitment and the typology of the offender's personality.

It is not just about administrative information, disciplinary information or civil information delicts, their social and legal consequences and the specifics of a person as the offender of information and legal regulations, but also about crimes in the field of information activity, typology of these offenders, their socially dangerous manifestation and so on.

${ }^{8}$ Алексеев Н. Н. Очерки по общей теории государства. Теория государства и права. Хрестоматия: учебное пособие. М. : «Интерстиль», 1998. С. 5.

9 Максименко Ю. С. Інформаційна деліктологія: проблемні питання. URL: http://goal-int.org/informacijna-deliktologiya-problemni-pitannya/

10 Цимбалюк В. С. Охорона та захист інформаційних ресурсів на засадах юридичної деліктології. Правова інформатика. 2007. № 4 (16). С. 23. 
Due to the given approach to understanding of the content of the category "subject matter of the science of information delictology," the science acquires a broad meaningfulness providing theoretical and methodological integrity of all information delicts and contributing to the formation of their integral doctrinally reasonable system based on common (generic) properties, as well as a unified set of causes and conditions that contribute to the development of informational tortness in Ukraine.

On the other hand, the coverage of the subject matter content of information delictology of different elements of information delicts facilitates the integral formation of theoretical understanding of the object of the corresponding legal science, provides the development of a unified and doctrinally reasonable mechanism for counteracting the dissemination of information torness, clarification the causes and conditions contributing to transition of some information and legal conflicts into others differed in socio-legal consequences.

As one of the key features of any science, the subject matter of information delictology, along with the performing of its contentforming function directly affects the system of the given science in a way of defining its internal structural components. Such a connection between the categories "subject" and "system" of information delictology also has a reverse manifestation of interaction, when the latter of these categories determines the logical construction of the subject matter of information delictology and the nature of functionalmethodological and conceptual connections of its internal elements.

From that perspective the system of information delictology acts as an internal structure of the science isolated by the generic substantive criterion and formed on the basis of the connection between its substantive components: information and delict standards; information tortness; the causes and conditions that contribute to the emergence of that antisocial phenomenon; a person violating legal prohibitions in the information area; preventive measures as well as the state programs for the prevention of information tortness, the body of which forms the subject matter of the science of information delictology.

The definition of the concept of "system" by L. von Bertalanffy: "the complex of interacting components" has been the most common in scientific literarure ${ }^{11}$.

${ }^{11}$ Берталанфи Л. Общая теория систем - критический обзор. Исследования по общей теории систем. М: Прогресс, 1969. С. 20. 
Such interpretation describes the concept "system" as a multitude of reality objects, endowed with common generic features and capable of ensuring their consistent interaction within an integral coordinated system.

According to the suggested definition of the concept "system" in the dictionary of 1913, it is a collection of objects that are clearly or orderly subordinated, as a rule the order can be logical or academic; a coherent whole of the objects connected by the general law, principle or purpose; the constant unification of principles or elements that form a coherent whole ${ }^{12}$.

In the dictionary of D. Ushakov (the first half of the 20th century), the category "system" is defined as "a construction, structure, which forms the unity of naturally located functioning parts ${ }^{13}$.

According to the interpretation of the category "system", given by S. Ozhegov and N. Shvedov (the second half of the 20th century), the system is something whole, that represents the integrity of parts which are logically located and stay in mutual communication ${ }^{14}$.

The use of the above mentioned definitions in the scientific area means that any science acquires the features of a separate system, provided that there are components selected in a separate group with target and substantive properties interconnected with logical principles, meaningfulness, theoretical and applied purposes within a single formation.

The first attempts to bring scientific knowledge of facts and phenomena characterized by delictology properties into an integrated, unified and logically connected system were made by Professor Ye. Dodinin within the science of administrative delictology. He proposed to define general and specific sections of the science of administrative delictology, each of them integrating particular elements that perform different methodological purposes ${ }^{15}$.

Wider views on the content of the analyzed concept were also suggested in terms of the science of administrative delictology.

${ }^{12}$ Webster's Revised Unabridged Dictionary. Chicago: The University of Chicago, 1913. P. 1465. URL: http://machaut.uchicago.edu/?resource=Webster\%27s\&word= system\&use $1913=$ on

${ }^{13}$ Толковый словарь Ушакова URL: http://www.onlinedics.ru/slovar/ ushakov/s/sistema.html

${ }^{14}$ Толковый словарь Ожегова URL: http://www.ozhegov-shvedova.ru/ 19-741515/СИСТЕМА

15 Додин Е. В. Административно-правовая наука и административная деликтология. Актуальные проблемы административной деликтологии : сборник научных трудов. Киев, 1984. С. 17. 
Hence, A. Deriuha suggests separation of general and specific parts within the system of administrative delictology, as well as administrative tortness prevention. In the opinion of the researcher, the general part covers the science-forming categories that include the subject matter and the object of study of delictology research, their balance, methods, the system and the principles of administrative delictology, balance between administrative delictology and other academic sciences. According to A. Deriuha, the functional approach in conducting administrative and delictology research is realized in its full manner.

The specific part covers the theory of administrative offenses prevention, knowledge about the peculiarities of certain types of administrative delicts commitment and the characteristics of persons committing them. Accordingly, the field approach to the study of administrative tortness is realized in terms of the special part that provides the development of private administrative delictology theories ${ }^{16}$.

The given views of scholars-administrativists are important for the formation of the concept of the science of information delictology taking into account the general nature of the methodological influence of administrative delictology on the formation of theoretical background of that particular legal science.

At the same time, the subject, methods, sources, principles of the science of informational delictology as well as the existence of special laws for the development of the information area stipulate the impossibility of a complete identification of the general and specific parts of the corresponding legal sciences.

First of all, this is due to the inclusion in the subject of information delictology information delicts with differing degrees of public danger. For that reason, the system of the given legal science should cover the measures of criminal-legal, administrative-legal, disciplinary-legal and civil-legal coercion including legal responsibility applicable for the violation of information statutory provisions, procedures for their implementation, as well as the mechanism for legal protection of the rights and interests of information relations participants.

16 Дерюга А. М. Концептуально-прекладные основы развития административной деликтологии : автореф. дис. ... докт. юрид. наук: спец. 12.00.14. М., 2012. C. 18 . 
Among the factors that directly affect the formation of the science of information delictology, the following must be emphasized:

1) The subject content of the given legal science research covering information delicts that differ in their specific features, preventive measures and legal consequences;

2) Methodological links of information delictology with other legal sciences that analize the unlawful conduct of individuals and legal entities: administrative delictology, criminology, legal conflictology, legal psychology, information, administrative and criminal law, etc.;

3) a wide range of general and special causes and conditions that facilitate the commitment of information delicts, which do not always arise in the exercising of information activity;

4) the use of the formulated conceptual apparatus as well as the conceptual apparatus borrowed from other legal sciences;

5) inter-area nature of legal measures of the commitment of information delicts prevention as well as the forms and the types of liability for information area violations, with their research as an integral part of the science of information delictology.

In our opinion, taking into account the direct influence of the group of the given factors on the formation of the system of the science of informational delictology, its internal structure can be determined through a broad interpretation of the subject of delictology research.

In our view, the concept, subject matter, object of study, principles, tasks, functions, sources, and methods of information delictology should be included in the components covered by the general part of the science of information delictology; the characteristic of the offender of information and legal restrictions and prohibitions, information-delict relations, their types and structure, the system for preventing the commitment of information delicts, providing information, legal protection and social values protection in the information area, general procedures for applying the appropriate category of legal remedies, the main principles of the formation and implementation of state information policy in the areas of information tortness prevention, legal protection and protection of social values of information area.

Thus, the specific part of the science of information delictology covers certain types of information delicts, special causes and conditions that facilitate their commitment, application of measures of legal coercion including measures of liability regarding to violators of 
information statutory provisions, means for the protection of certain categories of individual information rights and freedoms, peculiarities of legal investigation and judgment of certain categories of information disputes, etc.

Under current conditions of the information society evolution, the emergence of new types of information activity, the improvement of world models of e-government, the system of the science of information delictology cannot be regarded to as the constant and completely formed concept.

Under the influence of various delictology factors associated with the evolution of the information society, elements of the content of the science of information delictology have received a new interpretation, new functional and methodological connections have been formed among them that causes the formation of new sub-areas, institutes, subinstitutes and legal regulations which are covered by the content of the science of information delictology.

Hence, the obvious dialectic connection between the formation of the system of the science of information delictology and the existing conditions of the evolution of the information society can be traced based on specific theoretical problems that can be solved through realization of corresponding legal science issues.

\section{Methodology of Information Delictology}

The necessary attribute of any legal science that characterizes its integrity and the objective design of the system of knowledge about the subject of specific legal regulation has been its method.

The complex nature of the science of informational delictology, along with the lack of a unanimous scientific stance regarding to its place among other legal sciences in legal literature have led to the development of various doctrine views on the methods of information delictology.

According to O. Polushkin, information offenses have structurally complex nature due to the integrity of social-conflict, information and legal elements, which necessitates the use of the integrated, cross-area approach in the research of a specific category of delicts. The complexity of the nature of information violations stipilates the number of scientific research methods, the measures of the state legal policy implementation to prevent the abuse of information rights and freedoms, 
as well as the choice of methods for the prevention of information delicts and crimes related to the information area ${ }^{17}$.

The development of the view provided by O. Polushkin gives grounds to make an important conclusion for the formation of the methodology of the science of information delictology. Its essence is demonstrated by the fact that the complexity of information and delictology research and, as a consequence, the formation of a broad methodological apparatus of the science of information delictology is caused by the complex and structural nature of the information delicts.

Accordingly, the choice of the methods and measues of delictology research in the information area is determined by the content of the subject matter of the science of information delictology, as well as its tasks and objectives realized in the system of legal sciences.

According to another structural and functional approach, information delictology is considered as one of the sub-areas of information law, which determines the choice of delictology research methods of the first of the named legal sciences ${ }^{18}$.

At the same time, without going into disputes on the form of the correspondence of the science of informational delictology with the science of information law, it is necessary to emphasize the important clarification made by Yu. Maksymenko. Its essence is revealed in the existence of the most conceptual, functional and methodological connections between those legal sciences, therefore, elements of the science of information law penetrate into the content of information delictology.

Thus, for the formation of the science of information delictology methods, the content of its subject matter and object of research, the depth of its conceptual and functional-methodological connections with other legal sciences is crucial, as well as the purpose of this legal science in the mechanism of information law enforcement.

Close connection of information delictology with other legal sciences of delictology group has reflected in the structure of methodology apparatus of information delictology.

17 Полушкин А. В. Информационное правонарушение: понятие и виды: дис. ... канд. юрид. наук : спец. 12.00.14. Урал. гос. юрид. акад., каф. информ. права и естественнонауч. дисциплин. Екатеринбург, 2009. С. 8.

${ }_{18}$ Максименко Ю. Є. Засади розвитку інформаційної деліктології. Глобальна організація союзницького лідерства URL: http://goal-int.org/zasadi-rozvitkuinformacijnoi-deliktologii/ 
First of all the great influence on the formation of methodology apparatus of the science of information delictology is manifsted from the point of view of administrative delictology with the application of a great number of concepts, methods and theories in the conducting of information delictology research.

As with other legal sciences, the structure of the methodology of administrative delictology in literature is determined through the set of general scientific and specific scientific methods of cognition ${ }^{19,20}$.

According to legal scholars, the first group of the defined research methods is formed of dialectical, historical, formal-logical, sociological, statistical methods, the method of transition from abstract to specific, induction and deduction, and others. Specific scientific methods of administrative delictology traditionally include comparative-legal, specifically sociological, statistical, etc. ${ }^{21,22}$.

In our opinion, taking into account the identity of the common features of the content elements of all legal sciences of the delictology frame, such a classification of delictology research methods can be applied for the purposes of methodological apparatus construction of the science of information delictology with certain clarifications stipulated by the specifics of its subject matter and the object of study.

Dialectic method forms the basis for general scientific cognitive methods of socio-legal phenomena and processes that are covered by the content of the subject matter and the object of study of information delictology, Its application makes it possible to identify logical connections and contradictions between such philosophical categories as freedom, being, interests, needs, expressions of will and restrictions with the revealing of their content through the basic laws of dialectics.

The law of unity and struggle of opposites serves as a methodological basis for the study of the causes and conditions that facilitate the commitment of information delicts and the identification of

19 Дерюга А. М. Концептуально-прекладные основы развития административной деликтологии : автореф. дис. ... докт. юрид. наук: спец. 12.00.14. М., 2012. С. 7.

20 Абдрахманов Б. Е. Административная деликтология в республике Казахстан (концептуальные теоретические и методологические проблемы) : дис. ... докт. юрид. наук: спец. 12.00.02. Алмааты, 2010. С. 76.

${ }^{21}$ Никулин М. И. Проблемы науки административной деликтологии : дис. ... д-ра юрид. наук: спец. 12.00.14. Моск. Ун-т МВД России. М.: РГБ, 2006. С. 9.

22 Гензюк Э. Е. Административная деликтология : дис. ... д-ра юрид. наук. M., 2002. C. 5. 
individual features of the offender explaining predisposition to unlawful conduct with the reflection of special features inherent to the specific structure of information delicts. The application of this dialectic law also helps to determine the specific properties of information and communication technologies that induce a person to act in an unlawful manner, allow defining the factors encouraging the emergence of harmful properties of the components of the information area as well as situations where such factors become impossible or minimized.

The law of the transition of quantitative changes to qualitative ones explains the changes in the state and dynamics of information tortness, the tendency to qualitative changes in its types. The application of this dialectic law allows us to figure out the trends in the transition of administrative tortness into criminality within the information area as well as identify the factors that contribute to reducing the number of information delicts occurring on a particular territory over a specific period of time and reveal the socially harmful consequences of that category of unlawful acts ${ }^{23}$.

In conducting the research of complex information and legal concepts, processes and phenomena, information delictology is widely used as a method of transition from the abstract to the specific, which traditionally belongs to general scientific methods of cognition in gnoseology 24 .

The construction of information and delictology research on the principle of transition from abstract to specific contributes to the formation of generic concepts and categories used by information delictology through the involving of more specific elements of individual characteristics of information delicts to the system.

Such methodological approach in the process of scientific research regarding to the problems of information delicts prevention provides the opportunity of the solution of a complex problem involving theoretical and applied aspect. The problem includes the use of generaldelictological, criminological, sociological and other concepts and categories for the formation of a special conceptual apparatus of

${ }^{23}$ Заярний О. А. Правове забезпечення розвитку інформаційної сфери України: адміністративно-деліктний аспект : монографія. Херсон: Видавничий дім «Гельветика», 2017. С. 115, 116.

${ }^{24}$ Губерський Л. В., Надольний І. Ф., Андрущенко В. П. та ін. Філософія : навч. посіб.. 3-тє вид., стер. К.: Вікар, 2003. С. 162. 
information delictology as well as setting the limits of such borrowing. The purpose of the method of transition from abstract to specific in the structure of the methodological apparatus of information delictology is stipulated by the existence of deep, multilevel connections between scientific concepts, categories and laws within both the limits of any specific science and on the interdisciplinary level.

In the process of scientific cognition of socio-legal phenomena and processes that are covered by the subject of information delictology research, the method of transition from abstract to specific reveals the full potential of methods and measures in close connection with the method of analysis and synthesis.

Philosophy considers the latter of these methods as a comprehensive method of research, a set of techniques, operations and actions of the mental detachment of objects into constructive elements, properties (analysis) and their integration into a coherent whole (synthesis) when solving the cognitive task ${ }^{25}$.

The use of logical methods of analysis and synthesis in information delictology allows to distinguish those content-forming aspects and properties, on the basis of which it becomes possible to formulate new special concepts, in particular: "information delict", "information tortness", "information legal order", etc. . Due to synthetically formed concepts and categories, special features, properties and patterns of development obtain their logical implementation in appropriate structures, suitable for scientific application.

Their analysis allows identifying the common features of specific concepts developed by the information delictology aimed to provide the opportunity to combine them into wider generic structures. Based on that, legal scholars have a real opportunity to separate essential features that form the basis of both generic and specific concepts of the science of information delictology.

Another aspect of the method of analysis and synthesis application has been the ability to split information and delict concepts into individual types, that is, conduct their scientific classification according to different criteria. Attribution of classification method to the structure of the method of analysis and synthesis allows the use of the given method of cognition for structuring the system of scientific concepts of

${ }^{25}$ Сидоренко О. П. Філософія : підручник. К.: Знання, 2009. С. 146. 
information delictology in vertical and horizontal directions. In addition to that, the division of the whole into its constituent parts allows revealing the structure of the subject researched along with its the relationships between individual elements while separating the essential things from the non-essential ones and dividing complex things into simple ones ${ }^{26}$.

Due to such logical operations, the categories and concepts used by information delictology for characterizing of unlawful phenomena, objects and the processes in the information area acquire the features of scientific certainty.

Hence, the use of the complex of methods and measures pertaining to the method of analysis and synthesis in the issues of information delicts research contributes to the formation of the conceptual apparatus of information delictology, the increase of logical connections between its general and specific parts as well as the definition of the place of this science among other sciences of information area.

One of the general scientific methods widely used for scientific research in information delictology is the historical method. The use of that method makes it possible to analyze information tortness in its historical perspective, determine the main stages and conditions of its emergence and define the historical connections of this socio-legal phenomenon with criminality in the information area.

The research of the historical aspects of information tortness facilitates clarification of the legal nature of information delicts, the causes and conditions that contribute to their commitment.

On the basis of the historical method legal scholars make the selection of unlawful acts recognized as information delicts by the law for a long period of time; separation of information and legal conflicts acquiring the features of socially-harmful acts is made, or recommendations are drafted regarding to the necessity of certain components of such delicts criminality.

By revealing the primary roots of the phenomena and processes that make up the subject of the science of information delictology, the historical method makes it possible to determine the dynamic properties of the measures of information delicts prevention, construct their system

${ }^{26}$ Губерський Л. В., Надольний І. Ф., Андрущенко В. П. та ін. Філософія : навч. посіб.. 3-те вид., стер. К.: Вікар, 2003. С. 204. 
in accordance with periodization of the information society formation established by historical science and state the most effective measures of legal influence on the violators of information and legal prohibitions.

Incorporating of the historical method in the general scientific methodology of information delictology is also due to the variability of the state of information tortness as a social and legal phenomenon, the existence of which is associated with the historical development of the information society and the emergence of new interests and needs among its members that do not always correspond to the general principles of information legal order formation.

Application of the historical method in the given context allows analyzing of the causes and conditions that contribute to the development of information tortness in their dynamics, specifying the legal, economic, socio-psychological preconditions for the emergence of this phenomenon, separating the periods of historical development of the information society, which trace the tendency to the increase or decrease of the number of information delicts committed.

The system of specific scientific methods is widely used alongside with the general scientific methods of information delictology cognition.

Statistical method is of great importance among the above mentioned group of scientific methods ${ }^{27,28}$.

It helps to research quantitative and qualitative indicators of the development of information tortness and the personality of the violator of legal restrictions and proscriptions within the national information space. The application of that method in the study of various components of the subject of information delictology allows:

1) providing a comprehensive digital description of the development of information tortness at the state level, regional level or a separate branch of information activity for a specific period of time;

2) specifying the regularities of the development of information delicts on the territory of the state, a separate region, the condition of such tortness as well as its dynamics and structure;

3) characterizing the violators of information and legal prohibitions under socio-demographic, professional, economic and other criteria

27 Дерюга А. М. Концептуально-прекладные основы развития административной деликтологии : автореф. дис. ... докт. юрид. наук: спец. 12.00.14. М., 2012. С. 5.

${ }^{28}$ Никулин М. И. Проблемы науки административной деликтологии : дис. ... д-ра юрид. наук: спец. 12.00.14. Моск. Ун-т МВД России. М. : РГБ, 2006. С. 7. 
having information and delict significance (sex, age, level of professional training, form and type of information activity, number of completed information delicts);

4) determining in the digital dimension the distinctive, permanent and appropriate connections of information tortness with other types of illegal behavior taking place in the information area;

5) collecting and organizing the necessary digital materials, which can serve as the basis for identifying the causes and conditions that contribute to the development of information tortness, as well as its forecasting and the development of preventive measures for information delicts counteracting;

6) obtaining the necessary information that demonstrates the effectiveness of the application of measures of legal coercion to persons committed information delicts.

Such a multi-faceted application of the statistical method in the conduct of information and delict research leads to the possibility of its use not only in the process of general concepts and categories of information delictology study, but also for the study of certain types of information delicts, causes and conditions that contribute to their commitment, preventive measures, etc.

The analysis of the nature and purpose of the statistical method shows that the information obtained as a result of its application is widely used in the application of other general and scientific methods of the science of information delictology and serves as a key factor in determining the objectives and tasks of delictology research.

Based on that, the structure of the methodological apparatus of information delictology demonstrates close relationship of statistical method with comparative-legal method.

Special scientific nature of the latter of these methods of $\operatorname{cognition}^{29 ; 30}$ provides for the comparison of various components of the subject matter of information delictology. In particular, the following components of information delicts are compared: causes and conditions for their commitment and the characteristics of the violator of

${ }^{29}$ Манжул І. В. Визначення методів пізнання в науковій літературі. Бюлетень Міністерства юстиції Украӥни. 2012. № 11. С. 12.

30 Гаращук I. В., Петришин О. В. Порівняльно-правовий метод у дослідженні місцевого самоврядування. Державне будівництво та місиеве самоврядування. 2015. № 29. С. 56. 
information and legal prohibitions with similar notions, phenomena and categories stipulated by the existence of other types of unlawful conduct, namely, crime, economic tortness, etc.

According to the philosophers, "the effectiveness of the method is determined by the rules of application: to compare only homogeneous and interrelated objects, not to be limited in comparison with the establishment of only the similarity of objects, but necessarily identify the differences between them; compare objects by essential features". At the same time, "comparison is not the goal of cognition. According to the results of comparison the question inevitably arises of the problematic nature of new knowledge, the validity of the similarity of objects or the differences between them, the theoretical and practical possibilities of acquired knowledge implementation ".

Based on the given philosophical regularities and principles, information delictology reveals common and distinctive features of information tortness and criminality in the information area and causes and conditions common for both types of illegal conduct facilitating the violation of information statutory provisions, and establishes the regularities of the transition of administrative-information violation to information crimes, and vice versa.

Taking into account such designation of a comparative legal method in the information delictology, it is possible to distinguish several aspects of its emergence regarding to the investigation of information tortness:

1) the analysis of information delicts and information crimes for the purpose of identifying their common and distinctive features, and the research of adjacent components of such delicts on this basis;

2) the research of the content and structure of administrative-delict, criminal and other legal regulations imposing liability for information delicts in order to identify general and specific regularities of the formation of unlawful actions components in the information area, imposition of punishment for their commitment;

3) dynamics analysis of information tortness and other forms of illegal conduct in the information area, definition of common and diverse tendencies of increase or decrease of that social and legal phenomena manifestation;

4) study of state programs for preventing the commitment of information delicts concerning their effectiveness, content, compliance 
with the tasks of ensuring the security and protection of information rights, freedoms of the individual, information legal order in general, establishing of correlation changes in the field of information tortness;

5) identification of general and specific drawbacks in the organization of law enforcement activity in the field of prevention of information delicts commitment, determining the nature of their impact on information law enforcement.

Combining these aspects of the implementation of the comparative legal method within the science of information delictology indicates that the application of the given method allows lawyers to determine the place of the science among other legal sciences researching information area. The use of the comparative legal method also allows analyzing the system of the science of information delictology from the perspective of the improvement of its conceptual apparatus and internal structure based on the achievements of other legal sciences, namely, criminology, administrative delictology and legal conflictology.

Such a multilateral application of the comparative legal method indicates its omnitude for delictology research aimed to prevent information delicts, the ability to identify the concepts, patterns, trends and problems necessary for information delictology improvement. On the other hand, the scientific material accumulated as a result of the comparative legal method use can serve as the basis for the application of other specific scientific methods of cognition, focused on the tasks different from those solved by the comparative legal method ${ }^{31}$.

Explicitly sociological method is one of the specific scientific methods widely used in information delictology for the research of different aspects of its subject matter.

As far as the given method of cognition is specifically-scientific, it combines such means of information tortness cognition as observation, questioning, document analysis and experiment.

Administrative delictology and criminology provide the extended interpretation of the content of the specified instruments of the explicitly sociological method, in this connection they recognize the importance of independent methods of sociological research ${ }^{32 ; 33}$.

${ }^{31}$ Комзюк А. Т. Адміністративний примус в правоохоронній діяльності міліції в Україні : дис. докт. юрид. наук: спец. 12.00.07. Нац. Унт. Внутр. справ. Х., 2002. C. 24 .

32 Долгова А. И. Криминология : учебник. М., 2002. С. 49. 
However, despite the existence of scientific disputes on the internal structure of the explicitly sociological method of cognition, its structural elements are combined according to their purpose, that is, the study of social nature of information delicts and information tortness stipulated by their commitment, the nature of public assessment of these unlawful phenomena and socially harmful consequences caused by them. Taking into account such methodological views, the opinion of those scholars who consider observation, questioning, document analysis and experiment as techniques and means of explicitly sociological method within the limits of the science of administrative delictology is viewed more reasonable.

In general, application of the explicitly sociological method of research in information delictology allows identifying the social properties of the illegal conduct of the participants of information relations, expressed in the form of information delicts, defining the social causes and conditions that contribute to anti-social manifestations of information activity, revealing public assessment of information tortness.

In spite of some disputes and difficulties with the formation of the conceptual apparatus and the system, we can state the conceptual formation of the methodology of research in the science of information delictology, the integration of general scientific and specific methods in the process of various aspects of information tortness cognition.

At the same time, the conceptual formation of the methodological apparatus of the science of information delictology presupposes the existence of various theoretical and applied processes directly aimed at the improvement of certain methods of delictology research in the information area along with specialization and integration of the objects of cognition.

\section{CONCLUSIONS}

In general, the research of the scientific works devoted to various aspects of the science of information delictology in national and foreign legal doctrine points to theoretical separation and institutional composition of the system of knowledge of information delicts as well as causes and conditions that contribute to their commitment and the measures of

\footnotetext{
${ }^{33}$ Шиханцов Г. Г. Криминология : учебник. М.: Прогресс, 2001. С. 54.
} 
information tortness prevention along with the mechanism of legal responsibility for relevant delicts into a separate comlex legal science.

Recognition of the corresponding theoretical and methodological value of the information delictology, along with the doctrinal justification of its explicit substantive ties with other legal sciences examining the regularities of the development of the information area, provides a systematic study of information delicts, as well as the integration of the results into holistic theoretical and methodological basis of information delictology.

In the context of delictology research of the issues of the information area development and the commitment of the new types of unlawful acts within the national information space the content of the science of information delictology cannot be called completely formulated.

The following directions in the development of the science of informational delictology remain relevant for today, namely, the development of the theory of information delict; scientific provision of codification of the norms of legislation on information delicts and the responsibility for their commitment; scientific substantiation of the system of special penalties for information delicts commitment; research of the peculiarities of certain types of information delicts; scientific development of delictology aspects of the mechanism of legal provision for the development of the information area of Ukraine; scientific substantiation of the rules of delictolization or criminalization of unlawful acts committed in the information area; research of the peculiarities of legal procedures regarding to certain categories of information disputes arising from conflict proceedings, the formation of scientific recommendations for improving the practice of their investigation and resolution; the formation of methodological foundations and methodological recommendations for preventing information and legal conflicts emergence in the process of certain types of information activity exercising.

Thus, the national legal doctrine has necessary prerequisites for institutionalization of the system of knowledge on information delicts, measures for their prevention within the science of information delictology, creating theoretical foundations of the mechanism of legal responsibility for information statutory provisions violation on their basis, safety and protection of social values of information area. 


\section{SUMMARY}

In the conditions of negative dynamics in the commitment of information offences legal science faced the problem of the system of scientific knowledge formation about the specific category of delicts as well as causes and conditions for their commitment, peculiarities of preventive measures regarding to them and so on.

Information delictology has become the legal science that assumed the fulfillment of the respective tasks. The lack of a single view of the essence and the main components of information delictology (subject, object, methods, systems) in legal literature has led to the emergence of many controversial issues requiring their doctrinal solution.

The given paper makes an attempt of substantiation of the essence of scientific information delictology from doctrinal and law enforcement points of view, defining its subject, object and system as well as specifying the peculiarities of the methods of information violations delictology research.

The paper states that despite the lack of unified scientific understanding of the content of the concept, it covers the complex legal science, with the subject of study represented by information delicts, their features, components, the causes and conditions that contribute to the development of information tortness.

The conducted research demonstrated that the content of the constructive elements of the science of information delictology, namely, its subject, object and methods of research are mainly determined by the specifics of information violations, the legal content of measures for their prevention as well as the objectives of information security providing.

The result of the research has become the formulation of the main directions for further development of the science of information delictology in the conclusion of the paper, identification of the main doctrinal problems that require solution in the process of the subject, object and methods of legal science research improvement.

\section{REFERENCES}

1. Максименко Ю. Є. Інформаційна деліктологія: проблемні питання. URL: http://goal-int.org/informacijna-deliktologiya-problemnipitannya/ 
2. Цимбалюк В. С. Охорона та захист інформаційних ресурсів на засадах юридичної деліктології. Правова інформатика. 2007. № 4 (16). C. 13-24.

3. Арістова I. В., Баранов О. А., Дзьобань О. П. та ін. Юридична відповідальність за правопорушення в інформаційній сфері та основи інформаційної деліктології : монографія. Київ: КВІЦ, 2019. 344 c.

4. Руденко О.В. До проблеми співвідношення об'єкта та предмета наукового пізнання. Міжнародна наукова конферениія "Дні науки філософського фр-ту-2005” : матеріали доповідей та виступів. Частина 2. К.: ВПЦ “Київський університет”, 2005. С. 80-81.

5. Петровская О. В. Магистратура: проблемы методики преподавания юридических дисциплин : монография. М.: Высшее образование, Юрайт-Издат, 2012. URL: http://base.garant.ru/ $58085321 /$

6. Алексеев Н. Н. Очерки по общей теории государства. Теория государства и права. Хрестоматия : учебное пособие. М. : «Интерстиль», 1998. С. 5-10.

7. Додин Е. В. Административно-правовая наука и административная деликтология. Актуальные проблемы административной деликтологии : сборник научных трудов. Киев, 1984. С. 16-19.

8. Дерюга А. М. Концептуально-прекладные основы развития административной деликтологии : автореф. дис. ... докт. юрид. наук: спец. 12.00.14. М., 2012. 60 с.

9. Полушкин А. В. Информационное правонарушение: понятие и виды : дис. ... канд. юрид. наук : спец. 12.00.14. Урал. гос. юрид. акад. дисциплин. Екатеринбург, 2009. 26 с.

10. Абдрахманов Б. Е. Административная деликтология в республике Казахстан (концептуальные теоретические и методологические проблемы) : дис. ... докт. юрид. наук: спец. 12.00.02. Алмааты, 2010. 303 с.

11. Никулин М. И. Проблемы науки административной деликтологии: дис. ... д-ра юрид. наук: спец. 12.00.14. Моск. Ун-т МВД России. М. : РГБ, 2006. 420 с.

12. Гензюк Э. Е. Административная деликтология : дис. ... д-ра юрид. наук. М., 2002. 324 с. 
13. Заярний О. А. Правове забезпечення розвитку інформаційної сфери України: адміністративно-деліктний аспект : монографія. Херсон: Видавничий дім «Гельветика», 2017. 700 с.

14. Губерський Л. В., Надольний І. Ф., Андрущенко В. П. та ін. Філософія : навч. посіб. 3-тє вид., стер. К. : Вікар, 2003. 457 с.

15. Сидоренко О. П. Філософія : підручник. К.: Знання, 2009. $891 \mathrm{c}$.

16. Манжул I. В. Визначення методів пізнання в науковій літературі. Бюлетень Міністерства юстиції України. 2012. № 11. C. 11-17.

17. Гаращук I. В., Петришин О. В. Порівняльно-правовий метод у дослідженні місцевого самоврядування. Державне будівництво та місиеве самоврядування. 2015. № 29. С. 54-66.

\section{Information about the author:} Zaiarnyi O. A. Doctor of Law, Associate Professor, Associate Professor at the Department of Administrative Law, Taras Shevchenko National University of Kyiv 60, Volodymyrska str., Kyiv, Ukraine 